\title{
KARAKTERISTIK HUKUM ISLAM DALAM BIDANG EKONOMI
}

\author{
Ali Mutakin, Ghufron Maksum \\ Sekolah Tinggi Agama Islam Nurul Iman \\ Jl. Nurul Iman No. 1 Ds. Warujaya Rt. 01/01 Kec. Parung Kab. Bogor 16330 \\ Email: nabilamandor@gmail.com, ghufronmaksum@yahoo.com
}

\begin{abstract}
Abstrac
Al-Qur'an and Hadith are sources of Islamic law that have regulated all dimensions of human life, both those related to worship and mu'amalah. Islamic law which is associated with the original worship is regulated globally (mujmâl) in the Qur'an, then explained in detail by the Sunnah of the Prophet and formulated by jurists into fiqh books. Explanation of the Islamic Law related with mu'amalah is limited to the main points. Explanation of the Prophet, not as detailed as in his explanation of worship. Thus, mu'amalah has an open nature, so it is possible to develop through ijtihad by experts. While the characteristics of Islamic law, especially in muamalah, are perfect, universal, elastic, dynamic, flexible and not rigid, ta'aqquli and ta'abbudi, prioritizing substance rather than form, and creating benefit and not making it difficult. Islamic law is present on this earth, aiming to create benefit for all humanities, both in the world and the hereafter.
\end{abstract}

Keywords: Islamic Law, Characteristics, Mua'malah, Benefit

\begin{abstract}
Abstrak
Al-Qur'an dan Hadits merupakan sumber hukum Islam yang telah mengatur semua dimensi kehidupan manusia, baik yang berhubungan dengan ibadah maupun mu'amalah. Hukum Islam yang berkaian dengan ibadah semula diatur secara global (mujmâl) dalam Al-Qur'an, kemudian dijelaskan secara rinci oleh sunnah Rasul dan diformulasikan oleh para ahli hukum ke dalam kitab-kitab fikih. Adapun Hukum Islam yang berkaitan dengan mu'amalah penjelasannya terbatas pada yang pokok-pokok saja. Penjelasan Nabi, tidak serinci bagaimana dalam penjelasannya tentang ibadah. Dengan demikian, mu'amalah ini memiliki sifat yang terbuka, sehingga dimungkinkan adanya pengembangan melalui pintu ijtihad oleh para ahlinya. Sedangkan karakteristik hukum Islam khususnya dalam bidang muamalah adalah sempurna, universal, Elastis, dinamis, fleksibel dan tidak kaku, ta'aqquli dan ta'abbudi, mengutamakan substansi dari pada format, dan mewujudkan kemaslahatan dan tidak menyulitkan. Hukum Islam hadir di muka bumi ini, bertujuan untuk menciptakan kemaslahatan bagi seluruh umat manusia, baik di dunia maupun di akhirat.
\end{abstract}

Kata kunci: Hukum Islam, Karakteristik, Mua'malah, Kemaslahatan 


\section{A. Pendahuluan}

Al-Qur'an dan Hadits merupakan sumber hokum Islam telah mengatur semua dimensi kehidupan manusia, baik yang berhubungan dengan ibadah maupun mu'amalah. Meskipun demikian, tidak semua persoalan hidup manusia tersebut dapat ditemukan dalil-dalilnya secara rinci (tafshîli) dalam Al-Qur'an maupun Hadits Nabi. Hanya persoalan ibadah, dan perkawinan saja yang diatur secara rinci, selebihnya diatur secara global, yang perinciannya diserahkan kepada ulama yang membidangi dalam berijtihad. Karena keglobalan itulah yang pada akhirnya menjadikan hukum Islam selalu relevan dalam semua ruang dan waktu.

Atas dasar itulah maka, syariat Islam adalah syariat yang abadi. Keabadian ini, dimungkinkan antara lain karena ajaran-ajarannya baik yang terdapat dalam Al-Qur'an maupun Hadits, di samping ada yang

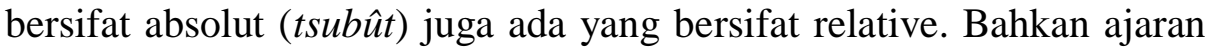
yang disebut terakhir ini, jauh lebih banyak jumlahnya daripada yang pertama. ${ }^{1}$ Dengan demikian, dapat dipahami bahwa ajaran yang bersifat absolut menjadikannya tetap terjaga dan terjamin sepanjang masa. Sedangkan dinamika ajaran Islamnya justeru terdapat pada ajaranajaran yang bersifat relative. ${ }^{2}$ Barangkali inilah yang diungkapkan oleh para ulama bahwa shâlihun li kulli az-zamân wa al-makân.

Berdasarkan uraian tersebut, makalah ini akan mendiskusikan tentang penjelasan masing-masing dari syari'at, fikih dan hukum Islam, tujuan hukum Islam beserta karakteristiknya.

\section{B. Pandangan Ulama Tentang Syari'ah, Fikih dan Hukum Islam}

Ada beberapa istilah yakni syari'ah, fikih dan hukum Islam yang acapkali dalam penggunaannya sering terjadi tumpang-tindih, bahkan sering terjadi miskonsepsi tradisional tentang hukum Islam sebagai sesuatu yang baku dan tidak bisa diotak-atik. Kekeliruan dalam memilih istilah tersebut, berdampak pada kekeliruan dalam mendiskripsikan bagaimana sejatinya hukum Islam itu sendiri, dan yang paling serius dampaknya adalah ketika terjadinya pembauran antara sesuatu yang bersifat profan dan sakral. Oleh karena itu, perlu kiranya diuraikan terlebih dahulu pandangan para ulama tentang masing-masing dari istilah tersebut.

\footnotetext{
${ }^{1}$ Muhammad Amin, Ijtihad Ibn Taimiyah Dalam Bidang Fikih (Jakarta: INIS, 1991) h. 39

${ }^{2}$ Muhammad Ani 'Ubadah, Târich al-Fiqh al-Islâmî fi 'Ahd an-Nubuwah wa as-Shahabah wa at-Tabi'in (Dâr Tiba'ah, 1980) h. 10
} 


\section{Syariah}

Menurut Said Al-Asymawi, kata syari'ah sudah digunakan sebelum Islam muncul, yaitu dalam kitab Taurat dan Injil, meskipun dalam kitab-kitab tersebut tidak menggunakan bahasa Arab, melainkan dengan bahasa Ibrani. Dalam kitab Taurat, disebutkan kata taurah yang berarti membimbing, memberi petunjuk, mengetahui, mengatur, bahkan terkadang diartikan sebagai undang-undang. Kata tersebut diulang sebanyak 200 kali dalam kitab Taurat. Sedangkan dalam kitab injil, Al-Masih menggunakan Namus guna menyebutkan syari'at seara umum yang berarti orang-orang yang dekat, ruh agama, dan syari'at nabi Musa.

Secara bahasa kata syarî'ah berarti "jalan ke tempat mata air" atau "tempat yang dilalui air sungai", namun bangsa Arab sering mengartikannya sebagai "jalan yang lurus", hal ini dikarenakan mata air merupakan sumber kehidupan. ${ }^{4}$ Sedangkan menurut istilah Asaf A.A. Fyzee menjelaskan bahwa syarî'ah adalah canon law of Islam, yaitu keseluruhan perintah Allah yang berupa nash-nash. ${ }^{5}$ Senada dengannya Satria Effendi menjelaskan bahwa syarî'ah adalah annushûsh al-muqaddasah yaitu nash yang suci yang terdapat dalam AlQur'an dan al-Hadits al-Mutawâtirah, yang belum tercampuri oleh pemahaman manusia. ${ }^{6}$ sehingga cakupan syarî'ah ini meliputi bidang i'tiqâdiyyah, 'amaliyah dan khuluqiyah. Hal ini nampak pada syariat setiap agama yang diturunkan sebelum Islam. Karena bagi setiap pemeluk agama tersebut, Allah memberikan syariat dan jalan yang terang. ${ }^{7}$ Inti aqidah dari agama-agama sebelum Nabi Muhammad dalah tauhid, maka dapat dipahami bahwa sejatinya cakupan syariah, adalah amaliah sebagai konsekuensi dari akidah yang diimani oleh setiap umat. Meskipun demikian, ketika digunakan kata syariat, maka pemahaman yang muncul adalah semua aspek ajaran Islam.

Sedangkan menurut as-Syat $\}$ ibi syari'at memberikan batasanbatasan (al-hudûd) bagi mukallaf, baik tentang perbuatan, perkataan

${ }^{3}$ Muhammad Said Al-Asymawi, Ushûl As-Syari'ah. Alih bahasa Luthfi Thomafi, (Yogyakarta: Elkis, 2004)h. 18

${ }^{4}$ Manna al-Qaththân, Tarîkh Tashrî' (Riyâd\}: Maktabah al-Ma'arif, 1996), h. 13

${ }^{5}$ Asaf A.A. Fyzee, The Outlines of Muhammadan Law (Delhi: Idarah-I Adabiyat-I, 1981), 19-20

${ }^{6}$ Satria Effendi, "Dinamika Hukum Islam" dalam Tujuh Puluh Tahun Ibrohim Hosen (Bandung: Remaja Rosdakarya, 1990), 312

${ }^{7}$ QS. Al-Maidah [5]: 48 
ataupun keyakinan-keyakinan. ${ }^{8}$ Bahkan syar'at ini juga seringkali disebut sebagai agama (millah atau dîn), dengan demikian syari'ah lebih luas cakupannya daripada fikih, karena syariah merupakan ajaran dari seluruh aspek agama, meskipun dalam bahasa Arab kata syari'ah lebih dahulu dikenal dibandingkan fikih. ${ }^{9}$ Dengan demikian, sejatinya syari'ah berbeda dengan fikih, meskipun fikih sendiri berasal dari syari'ah.

Dari uraian tersebut dapat disimpulkan bahwa syari'ah merupakan seperangkat aturan yang disyariatkan oleh Allah bagi umat manusia melalui Nabi Muhammad baik yang menyangkut urusan aqidah, ibadah, mu'amalah, akhlak dan aturan hidup guna mencapai suatu kebahagiaan di dunia dan akhirat.

\section{Fikih}

Jika syari'ah merupakan konsep ideal dan abstrak yang dikehendaki Allah, maka fikih dimaksudkan sebagai upaya manusia dalam memahami kehendak tersebut. ${ }^{10}$ Fikih secara etimologis berarti "faham", sedangkan menurut terminology fikih diartikan sebagai "pengetahuan tentang hokum-hukum syara' yang bersifat 'amaliyah yang digali (al-muktasab) melalui dalil-dalil yang terperinci”." Misalnya hokum wajib shalat, diperoleh ari dai peritah Allah dalam ayat "...aqîmû as-Shalât...". Karena dalam Al-Qur'an tidak dijelaskan bagaimana tatacara pelaksanaan shalat tersebut, maka dijelaskanlah oleh Hadits Nabi “... shallû kamâ ra'aytumû nî ushallî...”. Dari praktek Nabi inilah para sahabat, tabiin, dan fuqaha merumuskan tata aturan shalat yang benar sesuai dengan tuntunan Nabi dengan segala syarat dan rukunnya.

Jika diperhatikan dari definisi diatas, adanya kata al-muktasab (digali) menunjukan terdapat unsur manusiawi dalam menghasilkan / memproduksi hokum-hukum Islam. Selain itu, definisi diataspun juga menjelaskan bahwa antara syariah dan fikih memiliki hubungan yang sangat erat. Demikian itu dikarenakan, fikih merupakan formula yang

8 Ibrahim ibn Musa ibn Muhammad as-Shât\}ibi, al-Muwâfaqât Fî Ushûl asSyarî'ah (Beirut: Dâr Ibn 'Affân, 1997), Juz I, h. 131

9 Muhammad Yusuf Musa, Al-Islam Wa Hajat Al-Insaniyyah Ilaihi. Alih bahasa Malik Madani (Jakarta: Rajawali, 1988)h. 132

10 Khaled M. Aboe el-Fad\}1, Atas Nama Tuhan, Dari Fikih Otoriter ke Fikih Otoritatif. Alih bahasa Cecep Lukman Yasin (Jakarta: Serambi, 2004)h. 61

11 Abdul Wahhab Khallâf, 'Ilm Ushûl al-Fiqh (Beirût: Dâr al-Kuwaiiyah, 1968)h. 11 
dipahami dari syariah. Syariah tidak akan bisa dijalankan dengan baik, tanpa dipahami melalui fikih atau pemahaman yang baik dan memadai, dan diformulasikan dengan baku. ${ }^{12}$

Fikih sebagai hasil pemahaman, sangat dipengaruhi oleh tuntutan ruang dan waktu yang melingkupi faqîh sebagai orang yang memformulasikannya. Dengan demikian, sangat wajar jika kemudian terdapat ikhtilâf (perbedaan-perbedaan pendapat) dalam rumusan mereka. Hal ini dapat dilihat dalam catatan sejarah, bahwa terdapat fikih sunny (fikih yang berfaham ahl sunnah wa al-jamâ'ah), yang dikenal dengan fikih Hanafy, fikih Mâliky, fikih Syâfi'iy, fikih Hanbaly dan fikih Auza'iy meskipun yang terakhir ini kurang popular di Indonesia. Juga terdapat fikih syi $i \hat{i}$ (fikih yang mengaku pengikut Ali ibn Abî Thâlib). ${ }^{13}$

Asaf A.A. Fyzee dalam bukunya Outline of Muhammad Law, sebagaimana yang dikutip oleh Yayan Sopyan menguraikan dengan jelas tentang kedua istilah tersebut (syariah dan fikih). Jika syariah meliputi segala tingkah laku manusia, maka fikih hanya meliputi tindakan-tindakan hokum; jika syariat merupakan pengetahuan yang tak dapat dicapai kecuali melalui Al-Qur'an dan Hadits, maka fikih justeru mengutamakan akal untuk mengetahuinya; syariah ditentukan oleh Allah dan Rasulnya, sedangkan fikih ditentukan oleh usaha manusia; dalam fikih suatu tindakan dipandang sah atau tidak, boleh apa tidak, sementara dalam syariah suatu tindakan dipandang boleh atau terlarang; dan fikih merupakan istilah yang digunakan untuk hokum sebagai ilmu pengetahuan (science) sedangkan syariah digunakan bagi hokum sebagai jalan kebenaran sebagaimana diwahyukan oleh Allah. ${ }^{14}$

Dari uraian diatas, maka jika dipahami secara proporsional, terdapat karakteristik masing-masing antara syariah dan fikih. Pertama, syariah kebenarannya bersifat mutlak (absolut) karena ia diturunkan oleh Allah (syâri') yang karenanya ia adalah wahyu, sedangkan kebenaran fikih bersifat relative (nisbi) hal ini dikarena fikih merupakan formula hasil kajian fuqâha atau penalaran manusia terhadap wahyu tersebut. Kedua, syariah adalah satu (unity), sedangkan fikih beragam (diversity). Ketiga, syariah bersifat otoritatif, sedangkan

${ }^{12}$ Ahmad Rofiq, Hukum Islam di Indonesia (Jakarta: Raja Grafindo Persada, 1997) h. 4-5

13 Ahmad Rofiq, Hukum Islam di Indonesia...5-6

${ }^{14}$ Yayan Sopyan, Tarikh Tasyri': Sejarah Pembentukan Hukum Islam (Depok: Gramata Publishing, 2010) h. 6-7 
fikih berwatak liberal. Keempat, syariah bersifat stabil dan tidak bisa berubah seiring dengan perubahan zaman, sedangkan fikih mengalami perubahan eiring dengan tuntutan ruang dan waktu. Kelima, syariah bersifat idealistis, sedangkan syariah bercorak realistis. ${ }^{15}$

\section{Hukum Islam}

Istilah hukum Islam merupakan rangkaian dari kata "Hukum dan Islam", yang merupakan serapan dari bahasa Arab. Namun, apabila kedua kata tersebut disatukan menjadi satu istilah "Hukum Islam", maka tidak ditemukan dalam terminologi Arab, baik dalam Al-Qur'an, Hadits maupun literatur-literatur Arab lainnya. Menurut Yayan Sopyan istilah Hukum Islam muncul ketika di Indonesia muncul tiga hukum yang saling bersinggungan (trikotonomi hukum), yakni hukum Islam, hukum Adat dan hukum Barat. Penyebutan dengan istilah Hukum Islam, sebenarnya bertujuan untuk memisahkan antara hukum yang bersumber dari ajaran agama Islam, hukum yang berasal dari adat istiadat bangsa Indonesia dan hukum Barat yang dibawa oleh kolonial Belanda. $^{16}$

Terdapat beberapa rumusan yang dikemukakan oleh Ahlinya tentang Hukum Islam, diantaranya adalah rumusan yang dikemukakan oleh Amir Syarifuddin bahwa Hukum Islam adalah peraturan yang dirumuskan berdasarkan wahyu Allah dan Sunnah Rasul tentang tingkah laku mukallaf yang diakui dan diyakini berlaku mengikat bagi semua pemeluk Islam. ${ }^{17}$

Sementara Muhammad Daud Ali merumuskan Hukum Islam sebagai hukum yang bersumber dari dan menjadi bagian agama Islam. ${ }^{18}$ Sementara Fathurrahman Djamil menrumuskan bahwa Hukum Islam merupakan terjemahan dari bahasa Inggris "Islamic Law" mencakup rumusan dari kedua istilah sebelumnya yakni "syariah dan fikih". ${ }^{19}$

Sedangkan Menurut Abû al-'Ainain Badran seperti yang dikutip oleh Munif Suratmaputra menjelaskan bahwa secara garis besar Hukum Islam dapat diklasifikasikan menjadi tiga bagian. Pertama, Hukum

15 Noel J. Coulson, Conflict and Tension in Islamic Jurisprudence (Chigago: The Uniersity of Cigago Pres, 1969) h. 3

16 Yayan Sopyan, Tarikh Tasyri'....7

${ }^{17}$ Amir Syarifuddin, Pembaharuan Pemikiran Dalam Hukum Islam (Padang: Angkasa Raya, 1993), h. 18

${ }^{18}$ Muhammad Daud Ali, Hukum Islam (Jakarta: Raja Grafindo, 2006) h. 42

${ }^{19}$ Fathurrahman Djamil, Filsafat Hukum Islam (Jakarta: Logos, 1997) h. 12 
Islam yang berhubungan dengan perihal akidah atau keimanan yang kemudian menjadi kompetensi kajian ilmu tauhid. Kedua, Hukum Islam yang berkaitan dengan akhlak yang kemudian menjadi kompetensi kajian ilmu akhlak dan tasawwuf. Ketiga, Hukum Islam yang berhubungan dengan perbuatan mukallaf yang kemudian menjadi kompetensi kajian biang ilmu fikih dan usul fikih. Bagian ketiga inilah yang populer disebut sebagai Hukum Islam; sehingga apabila disebut Hukum Islam maka yang dimaksud adalah Hukum Islam yang berhubungan dengan perbuatan mukallaf. ${ }^{20}$

Terlepas dari adanya perbedaan pengertian tersebut, dalam khazanah pemikiran Hukum Islam selain fikih sebagaimana yang dijelaskan diatas, juga dikenal bahwa produk pemikiran Hukum Islam meliputi: ${ }^{21}$

a. Fatwa, yaitu produk pemikiran hukum yang muncul akibat suatu pertanyaan dari anggota masyarakat, selain itu fatwa harus didasarkan atas refleksi dari kondisi sosial yang melingkupinya. Fatwa bisa dilakukan oleh perorangan (fardi) dan juga bisa dilakukan secara kolektif (jamâ $i$ ). Produk fatwa tidak mempuyai daya ikat, bagi si peminta fatwa tidak harus mengikuti isi hukum fatwa yang diberikan kepadanya. Menurut Atho' Mudzhar sebagaimana yang dikutip oleh Ahmad Rofiq bahwa fatwa cenderung bersifat dinamis karena merupakan respon terhadap perkembangan baru yang sedang dihadapi oleh masyarakat si peminta fatwa. Meskipun demikian, isi fatwa itu sendiri belum tentu dinamis, karena boleh jadi diambil dari kitab-kitab fikih yang ada. $^{22}$

b. Putusan Pengadilan, yaitu produk hukum yang dikeluarkan oleh lembaga peradilan yang berdasarkan pemeriksaan perkara di depan persidangan. Hukum yang diputuskan tersebut disebut dengan istilah qadhâ', sedangkan lembaga yang mengeluarkan hukum disebut dengan al-wilâyah al- qadhâ', dan yang mengeluarkan hukum tersebut disebut dengan qâdhi atau hakim. Keputusan pengadilan ini bersifat mengikat kepada seluruh pihak-pihak yang berperkara. Meskipun sebagai produk lembaga yudikatif, keputusan pengadilan dapa dinilai sebagai yurisprudensi, yang

20 Ahmad Munif Suratmaputra, Filsafat Hukum Islam (Jakarta: Pustaka Firdaus, 2002) h. 9

${ }^{21}$ Yayan Sopyan, Tarikh Tasyri'...7-8. Lihat juga Ahmad Rofiq, Hukum Islam di Indonesia...8-9

${ }^{22}$ Ahmad Rofiq, Hukum Islam di Indonesia...33 
dalam kasus-kasus yang sama, dapat dijadikan sebagai reerensi hukum. Bahkan menurut Atho' Mudzhar sebagaimana yang dikutip oleh Ahmad Rofiq, bahwa keputusan pengadilan ini bersiat dinamis, karena ia berusaha untuk memberi jawaban atau menyelesaikan masalah yang diajukan kepada pengadilan pada suatu titik waktu tertentu. ${ }^{23}$

c. Perundang-undangan, yakni peraturan yang dibuat oleh suatu badan legislatif yang mengikat kepada setiap warga negara di mana undang-undangan itu diberlakukan, yang apabila dilanggar akan mendatangkan sanksi. Meskipun demikian, perundang-undangan ini mempunyai keterbatasan, diantaranya cakupan materi yang dimuat sangat spesifik, hanya mencakup bidang hukum tertentu saja. Misalnya undang-undang tentang perkawinan, yang didalamnya terdapat muatan-muatan Hukum Islamnya, ia mengikat semua warga masyarakat Indonesia. ${ }^{24}$

\section{Sifat dan Tujuan Hukum Islam}

Secara garis besar Hukum Islam dibagi menjadi dua. Pertama Hukum Islam yang berkaian dengan ibadah seperti shalat, puasa, zakat dan sebagainya yang pada intinya mengatur hubungan antara manusia dengan tuhannya. Ketentuan hukum ibadah ini, semula diatur secara global (mujmâl) dalam Al-Qur'an, kemudian dijelaskan secara rinci oleh sunnah Rasul -berupa ucapan, perbuatan atau penetapannya- dan diformulasikan oleh para ahli hukum ke dalam kitab-kitab fikih. Dengan demikian, sifat Hukum Islam yang berkaitan dengan ibadah ini, bersifat tertutup. Tidak ada modernisasi mengenai ibadah atau proses yang membawa perubahan dan perombakan secara asasi mengenai hokum, susunan, cara dan tatacara ibadah itu tersebut. Yang mungkin berubah hanyalah sarana atau penggunaan alat-alat modern dalam pelaksanaannya. Dengan kondisi yang demikian, mayoritas ahli hukum merumuskan asas umum hukum ibadah ini, bahwa pada dasarnya segala bentuk ibadah itu terlarang sampai adanya dalil yang

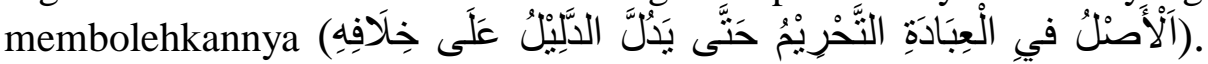
Asas ini diasumsikan bahwa ibadah harus ada contoh tata caranya dari Nabi, seperti shalat, wudlu' manasik haji dan sebagainya yang semua

\footnotetext{
${ }^{23}$ Ahmad Rofiq, Hukum Islam di Indonesia...33

${ }^{24}$ Ahmad Rofiq, Hukum Islam di Indonesia...33
} 
itu memerlukan petunjuk teknis dari Nabi. ${ }^{25}$ Prinsip ini berbeda dengan prinsip Hukum Islam bagian kedua yang akan dijelaskan yaitu yang berkaitan dengan mu'amalah.

Kedua, Hukum Islam yang berkaitan dengan mu'amalah yaitu yang mengatur hubungan antara manusia dengan sesamanya yang berkaitan dengan kehidupan sosial manusia, seperti perikatan, perkawinan, sanksi hukum dan sebagainya agar terwujud ketertiban dan keadilan, baik secara perorangan maupun kemasyarakatan. Hukum mu'amalah ini, terbatas pada yang pokok-pokok saja. Penjelasan Nabi, tidak serinci bagaimana dalam penjelasannya tentang ibadah. Dengan demikian, mu'amalah ini memiliki sifat yang terbuka, sehingga dimungkinkan adanya pengembangan melalui pintu ijtihad oleh para ahlinya. Oleh karena sifatnya yang demikian, maka berlakulah asas umum bahwa pada dasarnya semua perbuatan itu boleh, kcuali ada dalil

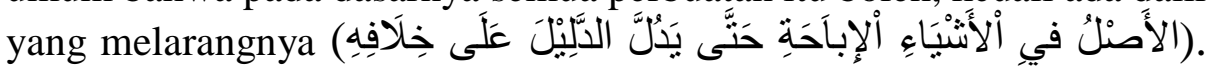
Abdul Wahâb Khalâf, ${ }^{26}$ membagi Hukum Mu'amalah ini menjadi tujuh aspek sesuai dengan tujuan masing-masing. Tujuh aspek tersebut adalah hukum kekeluargaan (ahwâl as-Shakhshiyyah) ${ }^{27}$, hukum sipil (al-ahkâm al-madaniyah $)^{28}$, hukum pidana (al-ankkâm al-jinâ'iyah) ${ }^{29}$, hukum acara (al-ahkâm al-murâfa $\hat{a} t)^{30}$, hukum ketatanegaraan (alahkâm al-dustûriyah) $)^{31}$, hukum internasional (al-ankâm al-

${ }^{25}$ Lihat As-Suyut \}î, Al-Asybah Wa An-Naz\}â' 'ir (Maktab Nur Asiya, tt) h. 4344

${ }^{26}$ Abdul Wahâb Khalâf, 'Ilm Ushûl Al-Fiqh (Jakarta: Maktabah Al-Da'wah Al-Islamiyah Syahab Al-Azhar, 1990) cet. Ke-8. h. 96

${ }^{27}$ Hukum yang berkaitan dengan urusan keluarga dan pembentukannya yang bertujuan untuk mengatur hubungan suami isteri dan keluarga satu dengan yang lainnya.

${ }^{28}$ Hukum yang mengatur hubungan individu-individu serta bentuk-bentuk hubungannya seperti jual beli, sewa menyewa, hutang piutang dan lain-lain, agar tercipta hubungan yang harmonis di dalam masyarakat.

${ }^{29}$ Hukum yang mengatur tentang bentuk kejahatan atau pelanggaran dan ketentuan sanksi hukumannya. Tujuannya agar terpelihara kehidupan manusia, harta, kehormatan, hak serta membatasi hubungan pelaku perbuatan pidana dan masyarakat.

30 Hukum yang mengatur tata cara mempertahankan hak, dan atau memutuskan siapa yang terbukti bersalah sesuai dengan ketentuan hukum. Hukum ini mengatur cara beracara di lembaga peradilan, tujuannya guna mewujudkan keadilan dalam masyarakat.

${ }^{31}$ Hukum yang berkenaan dengan system hukum yang bertujuan mengatur hubungan antara penguasa (pemerintah) dengan rakyatnya. 
duwaliyah $)^{32}$ dan hukum ekonomi/bisnis (al-ahkâm al-iqtishâdiyah wa al-mâliyah). ${ }^{33}$

Hukum Islam sebagai hukum yang berdasarkan kepada AlQur'an dan Hadits Nabi, hadir di muka bumi mempunyai tujuan yang hendak dicapai, yakni untuk kebahagiaan hidup manusia di dunia dan akhirat kelak, dengan jalan mengambil segala yang bermanfaat serta mencegah yang mudarat, yakni yang tidak berguna bagi hidup dan kehidupan. Dengan istilah lain, bahwa tujuan Hukum Islam adalah untuk merealisasikan kemaslahatan hidup baik rohani maupun jasmani, individual maupun sosial, di dunia maupun di akhirat kelak.

Menurut as-Shâthibi tujuan tersebut dapat dicapai manusia melalui dua hal. Pertama pemenuhan tuntutan sharî'at (taklîf), yaitu berupa usaha untuk menciptakannya (wujud) dengan melaksanakan perintah-perintah (awâmir) dan mempertahankan (ibqa') dari kehancurkanya dengan menjahui larangan-laranganya (nawâhi) yang terkandung dalam sharî'at tersebut. ${ }^{34}$

Pada dasarnya inti dari tujuan hukum atau yang lazim disebut dengan maqâshid as-Syarî'ah adalah kemaslahatan umat manusia. Berkaitan dengan hal ini as-Shâthibi menyatakan bahwa:

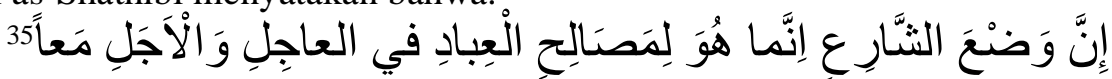
"sesungguhnya shâri' (pembuat sharî̀at) dalam mensharî̀atkan hukumnya bertujuan untuk mewujudkan kemaslahatan hambanya baik di dunia maupun di akhirat secara bersamaan”

Jika diperhatikan dari pernyataan as-Shâthibi tersebut, dapat ditarik kesimpulan bahwa kandungan maqâshid as-Syarî'ah adalah kemaslahatan manusia. Sejalan dengan pemikiran as-Shâthibi tersebut Fathi ad-Daryni menyatakan bahwa hukum-hukum itu tidaklah dibuat untuk hukum itu sendiri, melainkan dibuat untuk tujuan lain yakni

${ }^{32}$ Hukum yang mengatur tentang hubungan antar satu Negara-dengan Negara yang lain serta antara warga Muslim dengan non Muslim, baik dalam masa perang maupun damai.

33 Hukum ini mengatur hak-hak seorang pekerja dan orang yang mempekerjakannya, dan mengatur sumber keuangan Negara dan pendistribusiannya bagi kepentingan kesejahteraan rakyat.

${ }^{34}$ Lihat Abu Ishâq as-Shâthibî, al-Muwâfaqât fi Ushûli as-Syarî'ah, 7. Lihat juga fakhr al-Dîn al-Râzi, al-Mahhshûl fi Ilmi Ushûl al-Fiqh (Bayrut: Dâr al-Kutub, Juz II, 1999), 281-282

${ }^{35}$ Abu Ishâq as-Shâthibî, al-Muwâfaqât fi Ushûli as-Syarî'ah, 4 
kemaslahatan. $^{36}$ Sedangkan Muhammad Abu Zahrah menegaskan bahwa semua ajaran yang dibawa oleh Islam mengandung maslahat yang nyata. Allah menegaskan bahwa ajaran Islam baik yang terkandung dalam Al-Qur'an maupun Hadits Nabi merupakan rahmat, obat penyembuh dan petunjuk. ${ }^{37} \mathrm{Jadi}$, tujuan hakiki hukum Islam adalah untuk mewujudkan kemaslahatan. Tak satu pun hukum yang disyari'atkan baik dalam Al-Qur'an maupun Hadith melainkan di dalamnya terdapat kemaslahatan.

Penekanan inti dari maqâshid as-Syarî'ah yang dilakukan oleh as-Shâthibi secara garis besar bertitik tolak dari kandungan ayat-ayat Al-Qur'an yang menunjukan bahwa hukum-hukum Allah mengandung kemaslahatan. $^{38}$ Banyak ayat-ayat al-Qur'an maupun hadith yang berhubungan dengan hukum, setelah disimpulkan menunjukan bahwa semua hukum itu bermuara pada kemaslahatan, baik dalam rangka menarik atau mewujudkan kemanfaatan maupun menolak atau menghindari kerusakan.

Kemaslahatan tersebut dapat diwujudkan jika lima unsur pokok (ushûl al-khamsah) dapat diwujudkan dan dipelihara. Kelima unsur pokok tersebut adalah ad-dîn (agama), an-Nafs (jiwa), al-'aql (akal), an-nasl (keturunan), dan al-mâl (harta). ${ }^{39}$ Kenapa harus lima hal tersebut?. Hal ini disebabkan karena dunia, tempat manusia hidup, ditegakkan di atas pilar-pilar kehidupan yang lima itu. Tanpa terpeliharanya lima hal ini tidak akan tercapai kehidupan manusia yang luhur secara sempurna. Oleh karena itu, kemuliaan manusia tidak bisa dipisahkan dari pemeliharaan terhadap lima hal tersebut. ${ }^{40}$ Seorang Mukallaf akan memperoleh kemaslahatan, manakala ia dapat memelihara kelima aspek pokok tersebut, sebaliknya ia akan merasakan

${ }^{36}$ Fathi Daryni, al-Manâhij al-Ushûliyyah fî Ijtihâd bi al-Ra'yi fî̀ at-Tashrî̀' (Damshik: Dâr al-Kitâb al-hadîth, 1975), 28

${ }^{37}$ Muhammad Abu Zahrah, Ushûl Al-Fiqh, Saefullah Ma'shum (pent.) (Jakarta: Pustaka Firdaus, 200), cet. Ke-VIII, 552

${ }^{38}$ Ayat-ayat yang digunakan oleh as-Shâthibî antara lain adalah: Surat an-Nisa' ayat 165, surat al-Anbiya' ayat 107 tentang pengutusan Rasul, surat Hud ayat 7, surat al-Dhâriyât ayat 56, surat al-Mulk ayat 2 tentang penciptaan. Lihat Abu Ishâq asShâthibî, al-Muwâfaqât fi Ushûli as-Syarî̀'ah, 4

${ }^{39}$ Ushûl al-Khamsah sesuai urutanya adalah agama, jiwa, akal, keturunan dan harta. Tetapi ada sebagian ulama yang mendahulukan jiwa atas agama. Lihat Abu Ishâq as-Shâthibî, al-Muwâfaqât fî̀ Ushûli as-Syarî'ah, 8

${ }^{40}$ Muhammad Abu Zahrah, Ushûl Al-Fiqh, 548-549 
adanya mafsadah, manakala ia tidak dapat memeliharanya dengan baik. $^{41}$

Guna mewujudkan serta memelihara ushûl al-khamsah tersebut, maka maslahat dibagi kepada tiga tingkatan kepentingan, yaitu mashlahah al-dharûriyât, mashlahah al-hâjiyât dan mashlahah altahsininiât. Pembagian kemaslahatan ini perlu dilakukan guna menentukan tingkat kebutuhan dan skala prioritas dalam mengambil suatu kemaslahatan. Dalam hal ini berarti kemaslahatan tingkat aldharûriyât lebih didahulukan daripada kemaslahatan tingkat al-hâjiyât, dan kemaslahatan tingkat al-hâjiyât lebih didahukan daripada kemaslahatan tingkat al-tahsîniyât.

Mashlahah al-Dharûriyât merupakan maslahat yang bersifat essensial atau primer, dimana kehidupan manusia sangat tergantung padanya, baik kehidupan di akhirat maupun kehidupan di dunia. Ini merupakan sesuatu yang tidak dapat ditinggalkan dalam kehidupan manusia dan merupakan tingkat maslahat yang paling tinggi. Tidak terpenuhinya maslahat tersebut, maka mengakibatkan terancamnya eksistensi kehidupan di dunia maupun di akhirat. Guna menjaga maslahat ini ada dua solusi yakni, pertama merealisasikan dan mewujudkanya, kedua memelihara kelestarianya. Contoh menjaga agama (hifz al-dîn) dengan merealisasikan dan melaksanakan kewajiban-kewajiban agama seperti beriman, mengucapkan dua kalimah shahâdah, melaksanakan shalat, menunaikan zakat, puasa, haji dan lain sebaginya, serta memelihara kelestarian agama dengan berjihad menegakkan al-amar bi al-ma'ruf wa an-Nahyi 'an almunkar. ${ }^{42}$

Mashlahah al-Hâjiyât merupakan maslahat yang bersifat menyempurnakan atau sekunder, dimana kemaslahatan tersebut dibutuhkan oleh manusia untuk mempermudah dalam kehidupan dan menghindarkan manusia dari kesulitan dalam hidupnya. Tidak terealisasinya maslahat ini akan menimbulkan kesulitan dan kesempitan yang berimplikasi tidak sampai mengancam eksistensi kehidupan manusia. Contoh dalam bidang ibadah, diberikanya rukhshah meringkas (qashr) shalat dan berbuka puasa bagi orang sakit dan musafir. ${ }^{43}$

\footnotetext{
${ }^{41}$ Faturrahman Djamil, Metode Ijtihad Majlis Tarjih Muhammadiyah, (Jakarta: Logos Publishing House, 1995), 39

${ }^{42}$ Abu Ishâq as-Shâthibî, al-Muwâfaqât fi Ushûli as-Syarî'ah, 8

${ }^{43}$ Abu Ishâq as-Shâthibî, al-Muwâfaqât fi Ushûli as-Syarî'ah, 9
} 
Mashlahah al-Tahsîniyyât merupakan maslahat yang bersifat pelengkap atau tersier, dimana kemaslahatan tersebut sebagai penunjang tingkat martabat (muru'ah) guna meraih kabaikan dan akhlak yang mulia. Tidak adanya maslahat ini, tidak sampai merusak, mengancam ataupun menyulitkan kehidupan manusia. Contoh dalam bidang ibadah, menghilangkan najis, menutupi aurat, berpakaian yang bagus-bagus, melakukan ibadah-ibadah sunah. ${ }^{44}$

\section{Karakteristik Hukum Islam Dalam Bisnis}

Hukum Islam yang berhubungan dengan mu'amalah dalam arti khusus (al-ahkâm al-iqtishâdiyah wa al-mâliyah) selalu mengalami perkembangan dan perubahan sebagaimana sifat ajaran Islam yang fleksibel dan universal (shâlih li kulli al-zamân wa al-makân). Oleh karena itu, manusia diberi kebebasan untuk mengatur segala kebutuhan hidup yang serba dinamis, asalkan aturan-aturan yang dibuatnya tidak bertentangan dengan nash-nash Al-Qur'an maupun Hadits serta tujuantujuan utama syari'at (maqâshid As-Syari'ah).

Muhammad Rawas Qal'ahji telah mengidentifikasi ciri khas bisnis atau ekonomi dalam Islam adalah selalu terkait dengan akhlak (murtabithun bi al-akhlâq), selain itu juga bersifat objektif (almaudhu'iyyah). Dalam ajaran Islam, aktifitas ekonomi harus dilaksanakan secara objektif, karena pada hakikatnya aktifitas ekonomi merupakan amanat yang harus dipenuhi oleh setiap pelaku ekonomi tanpa membeda-bedakan jenis kelamin, warna kulit, etnik, agama dan sebagainya sehingga bentuk monopoli dalam ekonomi dilarang dalam Islam. ${ }^{45}$

Ciri khas tersebut pada akhirnya membentuk watak dan beberapa karakteristik Hukum Islam yang terkait dengan mu'amalah (ekonomi) yang membedakannya dari hukum yang lain. Diantara karakteristik tersebut adalah:

\section{Sempurna.}

Syari'at itu akan selalu sesuai dengan segala situasi dan kondisi manusia, dimana pun dan kapan pun, baik sendiri maupun berkelompok. Hal ini didasarkan bahwa syariat Islam diturunkan dalam bentuk yang umum dan hanya garis besar permasalahannya saja, sehingga hokum-hukumnya bersifat tetap meskipun zaman dan tempat

\footnotetext{
${ }^{44} \mathrm{Abu}$ Ishâq as-Shâthibî, al-Muwâfaqât fi Ushûli as-Syarî'ah, 9

45 Muhammad Rawas Qal'ahji, Mabahith Fi al-Iqtishâd al-Islâmî Min Ushûlihi al-Fiqhiyyah (Beirut, 2000)h. 54
} 
selalu berubah. Penetapan hokum yang bersifat global oleh Al-Qur'an tersebut dimaksudkan untuk memberikan kebebasan kepada umat manusia untuk melakukan ijtihad sesuai dengan situasi dan kondisi ruang dan waktu. ${ }^{46}$

\section{Universal}

Hukum Islam yang terkait dengan mu'amalah ini dibangun di atas prinsip universal seperti nilai-nilai keadilan (al-'adâlah), kesetaraan/egeliter (al-musâwah), kemerdekaan (al-hurriyah), saling membantu (al-ta'âwun), toleransi (al-tasâmuh), berbuat kebaikan (alihsân), tanggungjawab (mas'uliyah), keseimbangan (wasathiyah) dan lain sebagainya. Prinsip-prinsip diatas tersebut akan menciptakan hubungan-hubungan sosial yang berkeadilan dan anti ketimpangan. Pengaplikasian prinsip-prinsip tersebut dalam suatu perjajian atau perikatan, maka itu diyakini tidak hanya berlaku di dunia saja, tetapi juga memperhitungkan jangka panjang di akhirat kelak. Konkritnya yaitu menjaga diri dari tindakan-tindakan yang merugikan atau merusak serta sikap yang tidak bertanggungjawab. ${ }^{47}$

\section{Elastis, dinamis, fleksibel dan tidak kaku.}

Hokum Islam merupakan syariat yang universal dan sempurna, maka tidak dapat dipungkiri pula kesempurnaannya ini membuatnya bersifat elastis, fleksibel, dan dinamis dalam perkembangan zaman, karena jika hokum Islam menjadi sesuatu yang kaku justeru akan menjadikannya tidak relevan pada masa atau ruang tertentu. Bila syariat diyakini sebagai sesuatu yang baku dan tidak pernah berubah, maka fikih menjembatani antara sesuatu yang baku (syariat) dan sesuatu yang relative dan terus berubah tersebut. Syariat Islam hanya memberikan kaidah dan patokan dasar yang umum/global. Perinciannya disesuaikan kepada kebutuhan manusia dan dapat berlaku dan diterima oleh seluruh manusia. Dengan ini pula, dapat dilihat bahwa hokum Islam mempunyai daya gerak dan hidup yang dapat membentuk diri sesuai engan perkembangan dan kemajuan, melalui suatu proses yang disebut ijtihad. Ijtihad merupakan prinsip gerak dalam Islam yang akan mengarakan Islam kepada suatu perkembangan yang bersifat aktif, produktif serta konstrukstif. ${ }^{48}$

\footnotetext{
${ }^{46}$ Yayan Sopyan, Tarikh Tasyri'....11

${ }^{47}$ Soffa Ihsan, Fikih Perlindungan Konsumen (Ciputat: Putaka Cendekiamuda, 2011) h. 68-69

${ }^{48}$ Yayan Sopyan, Tarikh Tasyri'....12
} 


\section{Ta'abbudi dan Ta'aqquli.}

Syari'at bisa dibedakan menjadi dua warna, yaitu ta'abbudi dan ta'aqquli. Ta'abbudi merupakan bentuk ibadah yang berfungsi untuk mendekatkan manusia kepada Allah. Bentuk ibadah ini sudah given, taken from granted, makna yang terkandung didalamnya tidak dapat dinalar, irrasional. Sedangkan ta'aqquli adalah bersifat duniawi yang maknanya dapat difahami oleh nalar manusia dan rasional. Oleh karena itulah mu'amalah sering juga disebut sebagai 'ibâdah ghayr almahdhah yaitu bentuk ibadah yang bersifat duniawi. ${ }^{49}$

\section{Mengutamakan substansi dari pada format.}

Prinsip dasar dari bidang mu'amalah ini sejatinya didasari oleh prinsip suka sama suka (tarâdhin) sebagai substansinya. Sedangkan ijab dan kabul (bentuk verbal) tidak lain hanyalah format yang memanifestasikan prinsip tarâdhin tersebut. Dalam jual beli misalnya, sangat memperhatikan prinsip tarâdhin tersebut sebagai substansinya, sedangkan keberadaan ijab dan kabul tersebut, merupakan bentuk pengejahwantahan dari pada prinsip tarâdhin. Kondisi demikian, dikarenakan dalam mu'amalah dimensi luar bisa aja berubah sesuai dengan perkembangan peradaban umat manusia. تغير الاحكام بتغير الازمنة و الامكنة و العو ائد (perubahan hukum disebabkan oleh perubahan waktu, tempat dan niat).

\section{Mewujudkan kemaslahatan dan tidak menyulitkan.}

Hal ini terermin dari maksud dan tujuan Hukum Islam itu diturunkan, bahwa tiada lain tujuannya hanyalah untuk mewujudkan kemaslahatan bagi umat manusia baik di dunia maupun akhirat. Oleh karena itu, dalam bermu'amalah -bisnis- akan senantiasa berusaha mewujudkan kemaslahatan, mereduksi permusuhan dan perselisihan di antara manusia. Allah sebagai shâri' menurunkan syariat tidak bermaksud untuk memberikan beban yang menyulitkan, memberatkan, serta menyempitkan ruang gerak kehidupan manusia. ${ }^{50}$

\section{E. Penutup}

Dari uraian tersebut dapat disimpulkan bahwa syariat merupakan seperangkat aturan yang disyariatkan oleh Allah bagi umat manusia

\footnotetext{
${ }^{49}$ Yayan Sopyan, Tarikh Tasyri'....12

${ }^{50}$ Yayan Sopyan, Tarikh Tasyri'.....12-13
} 
melalui Nabi Muhammad baik yang menyangkut urusan aqidah, ibadah, mu'amalah, akhlak dan aturan hidup guna mencapai suatu kebahagiaan di dunia dan akhirat. Sedangkan fikih adalah pengetahuan tentang hukum-hukum syara' yang bersifat 'amaliyah yang digali (almuktasab) melalui dalil-dalil yang terperinci. Jadi jika syari'ah merupakan konsep ideal dan abstrak yang dikehendaki Allah, maka fikih dimaksudkan sebagai upaya manusia dalam memahami kehendak tersebut. Sedangkan Hukum Islam adalah peraturan-peraturan yang dirumuskan berdasarkan wahyu Allah dan Runnah Rasul tentang tingkah laku mukallaf yang diakui dan diyakini berlaku mengikat bagi semua pemeluk Islam.

Adapun tujuan disyari'atkannya hukum Islam adalah untuk mewujudkan kemaslahatan umat baik di dunia maupun di akhirat. Kemaslahatan tersebut bisa dicapai dengan upaya meraih yang maslahat dan menolak yang mafsadah. Keseluruhan taklif yang yang tercermin dalam al-ahkâm al-khams (wajib, sunnah, haram, makruh dan mubah) kembali untuk kemaslahatan hamba Allah baik di dunia maupun di akhirat.

Sedangkan karakteristik hukum Islam khususnya dalam bidang muamalah adalah sempurna, universal, Elastis, dinamis, fleksibel dan tidak kaku, ta'aqquli dan ta'abbudi, mengutamakan substansi dari pada format, dan mewujudkan kemaslahatan dan tidak menyulitkan.

\section{Daftar Pustaka}

al-Asymawi, Muhammad Said. Ushûl As-Syari'ah. Alih bahasa Luthfi Thomafi. Yogyakarta: Elkis, 2004

Ali, Muhammad Daud. Hukum Islam. Jakarta: Raja Grafindo, 2006 al-Qaththân, Manna. Tarîkh Tashrî́. Riyâdh: Maktabah al-Ma'arif, 1996

ar-Râzi, Fakhr al-Dîn. al-Mahhshûl fi Ilmi Ushûl al-Fiqh. Bayrut: Dâr alKutub, Juz II, 1999

as-Shâthibi, Ibrahim ibn Musa ibn Muhammad. al-Muwâfaqât Fî Ushûl as-Syarî'ah. Beirut: Dâr Ibn 'Affân, 1997. Juz I

as-Suyuthî, Al-Ashbah Wa An-Nazhâ' 'ir. Maktab Nur Asiya, tt.

Coulson, Noel J. Conflict and Tension in Islamic Jurisprudence.

Chigago: The Uniersity of Cigago Pres, 1969

Daryni, Fathi. al-Manâhij al-Ushûliyyah fî Ijtihâd bi ar-Ra'yi fî alTashrî’. Damshik: Dâr al-Kitâb al-hadîth, 1975

Djamil, Faturrahman. Metode Ijtihad Majlis Tarjih Muhammadiyah,. Jakarta: Logos Publishing House, 1995 
Filsafat Hukum Islam. Jakarta: Logos, 1997

Effendi, Satria. "Dinamika Hukum Islam" dalam Tujuh Puluh Tahun Ibrohim Hosen. Bandung: Remaja Rosdakarya, 1990

el-Fadhl, Khaled M. Aboe. Atas Nama Tuhan, Dari Fikih Otoriter ke Fikih Otoritatif. Alih bahasa Cecep Lukman Yasin. Jakarta: Serambi, 2004

Fyzee, Asaf A.A. The Outlines of Muhammadan Law. Delhi: Idarah-I Adabiyat-I, 1981

Ihsan, Soffa. Fikih Perlindungan Konsumen. Ciputat: Putaka Cendekiamuda, 2011

Khallâf, Abdul Wahhab. 'Ilm Ushûl al-Fiqh. Beirût: Dâr alKuwaitiyah, 1968

Musa, Muhammad Yusuf. Al-Islam Wa Hajat Al-Insaniyyah Ilaihi. Alih bahasa Malik Madani. Jakarta: Rajawali, 1988

Rofiq, Ahmad. Hukum Islam di Indonesia. Jakarta: Raja Grafindo Persada, 1997

Sopyan, Yayan. Tarikh Tasyri': Sejarah Pembentukan Hukum Islam. Depok: Gramata Publishing, 2010

Suratmaputra, Ahmad Munif. Filsafat Hukum Islam. Jakarta: Pustaka Firdaus, 2002

Syarifuddin, Amir. Pembaharuan Pemikiran Dalam Hukum Islam. Padang: Angkasa Raya, 1993

Zahrah, Muhammad Abu. Ushûl Al-Fiqh, Saefullah Ma'shum (pent.). Jakarta: Pustaka Firdaus, 200, cet. Ke-VIII 
Ali Mutakin, Ghufron Maksum

228 | Al Ashriyyah, Vol. 5 No. 2 Oktober 2019 